\title{
Faktor-Faktor Yang Berpengaruh Terhadap Kepatuhan Wajib Pajak Dalam Membayar Pajak Bumi Dan Bangunan
}

\author{
M. Hasan Ma'ruf ${ }^{1)}$, Sri Supatminingsih ${ }^{2)}$ \\ Sekolah Tinggi Ilmu Ekonomi AAS Surakarta \\ Email Korespondensi : hasan.stie.aas@gmail.com
}

\begin{abstract}
This study aims to examine the effect of awareness of taxpayers, the level of understanding of taxes, the implementation of sanctions and the quality of service on tax compliance in paying taxes and building (PBB). The sampling technique in this study uses convenience sampling for 100 earth taxpayers in Sukoharjo who meet the criteria. The data used are primary data through a questionnaire, which contains respondents' answers. Data analysis in this study uses descriptive analysis and multiple linear regression analysis. The results of this study, first: awareness of taxpayers have a positive effect on compliance with land and building taxpayers, second: the level of understanding has a positive effect on compliance with land and building taxpayers, third: the implementation of sanctions has a positive effect on compliance with land and building, the fourth: quality of service has a positive effect on compliance with land and building taxpayers. The results also showed that awareness of taxpayers, tax sanctions, tax understanding, and service quality simultaneously had positive effects on land and building tax compliance
\end{abstract}

Keywords: tax awareness, tax sanctions, tax understanding, service quality, compliance, taxpaye

\section{PENDAHULUAN}

Setiap individu dalam masyarakat harus dapat memahami dan mengerti akan arti penting pajak dalam keberhasilan suatu pemerintahan bahwa pajak merupakan sumber pendapatan negara yang mempunyai peranan yang sangat penting didalam pelaksanaan pembangunan, selain Pajak Pendapatan dan Pajak Penghasilan maka Pajak Bumi dan Bangunan atau PBB juga memberikan peranan penting dalam Sumber Pembiayaan.

Pembayaran yang dilakukan oleh wajib pajak khususnya dalam pembayaran PBB akan dipergunakan untuk kepentingan masyarakat secara umum. Uang pajak digunakan untuk pembiayaan dalam rangka memberikan rasa aman bagi seluruh lapisan masyarakat. Setiap warga negara mulai saat dilahirkan sampai dengan meninggal dunia, menikmati fasilitas atau pelayanan dari pemerintah yang semuanya dibiayai dengan uang yang berasal dari pajak. Pajak juga digunakan untuk mensubsidi barang- barang yang sangat dibutuhkan masyarakat dan juga membayar utang negara ke luar negeri. Pajak juga digunakan untuk membantu Usaha Mikro, Kecil dan Menengah (UMKM) baik dalam hal pembinaan dan modal. Dengan demikian jelas bahwa peranan penerimaan pajak bagi suatu negara menjadi sangat dominan dalam menunjang jalannya roda pemerintahan dan pembiayaan pembangunan. Disamping fungsi budgeter (fungsi penerimaan) di atas, pajak juga melaksanakan fungsi redistribusi pendapatan dari masyarakat yang mempunyai kemampuan ekonomi yang lebih tinggi kepada masyarakat yang kemampuannya lebih rendah.

Permasalahan yang dihadapi oleh pemerintah daerah dalam hal pemungutan atas PBB adalah asas kepatuhan wajib pajak, kurangnya pengetauhan wajib pajak membuat pendapatan pemerintah daerah dari PBB tidak maksimal. Oleh karena itu tingkat kepatuhan wajib pajak dalam melaksanakan kewajiban 
perpajakannya secara baik dan benar merupakan syarat mutlak untuk tercapainya fungsi redistribusi pendapatan. Sehingga pada akhirnya kesenjangan ekonomi dan sosial yang ada dalam masyarakat dapat dikurangi secara maksimal.

Sejalan dengan pelaksanaan otonomo daerah dimana daerah diberi kebebasan untuk mengelola dan mengatur pendapatan yang dimiliki maka PBB juga dikelola sepenuhnya oleh Pemerintah Daerah Kabupaten Sukoharjo dalam hal ini Dinas Pendapatan Pengelolaan Keuangan dan Aset. Hal tersebut didasarkan pada UU Nomor 28 tahun 2009 tentang Pajak Daerah dan Retribusi Daerah, bahwa kewenangan pemungutan Pajak Bumi dan Bangunan Sektor Perdesaan dan Perkotaaan dialihkan dari Pemerintah Pusat kepada masingmasing Pemerintah Kabupaten/Kota paling lambat tahun 2014 dan telah ditindaklanjuti dengan Peraturan Daerah kabupaten Sukoharjo Nomor 13 Tahun 2011 tentang Pajak Bumi dan Bangunan Perdesaan dan Perkotaan serta Peraturan Bupati Sukoharjo Nomor 15 Tahun 2012 tentang Pedoman Pelaksanaan Peraturan Daerah Nomor 13 Tahun 2013 tentang Pajak Bumi dan Bangunan Perdesaan dan Perkotaan.

Penerimaan Pajak Bumi dan Bangunan yang diterima oleh Kabupaten Sukoharjo dari tahun 2014- 2017 belum dapat memenuhi target yang ditetapkan oleh Pemerintah Daerah Kabupaten Sukoharjo. Pada tahun 2014-2017 yang rata-rata hanya berkisar pada angka $87.55 \%$ hingga $97.65 \%$ menunjukkan bahwa kesadaran dari wajib pajak, khususnya Pajak Bumi dan Bangunan di Kabupaten Sukoharjo masih perlu ditingkatkan. Dari data yang diperoleh berdasarkan Laporan PAD Kabupaten Sukoharjo tahun 2014-2017, diketahui bahwa terdapat beberapa penyebab mengapa potensi PAD yang berasal dari PBB belum dapat dimaksimalkankan. Fenomena ini menjadikan peneliti tertarik untuk melakukan penelitian perpajakan di wilayah Kabupaten Sukoharjo.

\section{TINJAUAN PUSTAKA}

Wajib Pajak Bumi dan Bangunan

Subjek pajak adalah pihak-pihak (orang maupun badan) yang akan dikenakan pajak dan yang dimaksud dengan objek pajak yaitu sesuatu yang dikenakan pajak atau dapat diartikan sebagai sasaran pengenaan pajak. Subyek pajak bumi dan bangunan adalah orang atau badan yang mempunyai kewajiban untuk melunasi PBB sesuai dengan ketentuan UU PBB. Subyek PBB baru akan melunasi utang $\mathrm{PBB}$ apabila subyek PBB tersebut secara nyata mempunyai suatu hak atas bumi dan bangunan dan atau memperoleh manfaat atas bumi dan bangunan.

\section{Pajak Bumi dan Bangunan (PBB)}

1. Pengertian

Pajak Bumi dan Bangunan (PBB) adalah pajak negara yang dikenakan terhadap bumi dan/atau bangunan berdasarkan Undang-undang nomor 12 Tahun 1985 tentang Pajak Bumi dan Bangunan sebagaimana telah diubah dengan Undang-Undang N12 Tahun 1994. Yang kemudian disempurnakan lagi dengan Undang-undang No.13 Tahun 2013.

2. Sifat Pajak Bumi dan Bangunan

PBB adalah pajak yang bersifat kebendaan dalam arti besarnya pajak terutang ditentukan oleh keadaan objek yaitu bumi/tanah dan/atau bangunan. Keadaan subjek (siapa yang membayar) tidak ikut menentukan besarnya pajak. PBB ini belum didasarkan pada self assessment seperti yang telah diberlakukan untuk pajakpajak lainnya. Pemerintah berpendapat mengingat tingkat pendidikan dan pemahaman sebagian besarmasyarakat masih rendah maka untuk sementara waktu belum dapat menerapkan.

3. Objek Pajak Bumi dan Bangunan

Objek PBB menurut undang-undang PBB (Pasal 2 UU PBB) adalah bumi dan atau bangunan. Bumi adalah permukaan bumi dan tubuh bumi yang ada dibawahnya, sedangkan bangunan adalah konstruksi teknik yang ditanam atau dilekatkan secara tetap pada tanah dan atau perairan.

4. Subjek Pajak Bumi Dan Bangunan

Pahala (2011:110) subjek PBB menurut Pasal 4 UUPBB adalah orang atau badan yang secara nyata mempunyai 
suatu hak atas bumi, dan atau memperoleh manfaat atas bumi, dan atau memilikimenguasai, dan atau memperoleh manfaat atas bangunan.

5. Nilai Jual Objek Pajak Tidak Kena Pajak (NJOPTKP)

Besarnya Nilai Jual Objek Pajak Tidak Kena Pajak ditetapkan sebesar Rp. 8.000.000,00 (delapan juta rupiah) untuk setiap wajib pajak. Apabila wajib pajak mempunyai beberapa objek pajak, yang diberikan Nilai Jual Objek Pajak Tidak Kena Pajak hanya salah satu objek pajak yang nilainya terbesar.

6. Sanksi Perpajakan Pajak Bumi dan Bangunan (PBB)

Apabila wajib pajak PBB tidak melunasi pembayaran PBB sesuai dengan batas waktu yang telah ditetapkan maka wajib pajak dapat dikenai sanksi/denda administrasi sebesar $2 \%$ perbulan maksimal selama 24 bulan berturut-turut atau total denda administrasi sebesar 48\%. Media pemberitahuan pajak yang terutang melewati batas waktu yang terlah ditetapkan adalah dengan Surat Tagihan Pajak (STP). Jika dalam waktu 30 hari setelah STP terbit belum ada pembayaran dari WP, maka dapat diterbitkan Surat Paksa (SP) sesuai dengan pasal 13.

\section{Faktor yang Mempengaruhi Penerimaan PBB}

1. Faktor Kesadaran Perpajakan

Kesadaran perpajakan adalah sikap wajib pajak terhadap fungsi pajak, keberhasilan perpajakan sangat ditentukan oleh kesadaran perpajakan wajib pajak. Kepatuhan pajak lain dari kesadaran pajak. Kesadaran perpajakan berkonsekuensi logis untuk para wajib pajak agar mereka rela memberikan kontribusi dana untuk pelaksanaan fungsi perpajakan, dengan cara membayar kewajiban pajaknya secara tepat waktu dan tepat jumlah.

Kesadaran perpajakan adalah kerelaan memenuhi kewajibannya, termasuk rela memberikan kontribusi dana untuk pelaksanaan fungsi pemerintah Dengan cara membayar kewajiban pajaknya

(Suhardito,B.\& Sudibyo,B.1999). Variabel ini diukur dengan menggunakan Instrument yang dikembangkan oleh Sulistriorini, E. (2003) dengan indikator sebagai berikut:

a. PBB dipergunakan sebagai sumber pendapatan negara.

b. PBB harus dibayar tepat waktu untuk pembiayaan pembangunan.

c. PBB harus dibayar karena kewajiban warga negara.

d. PBB sebagai sumber pendapatan negara

2. Faktor Pemahaman Wajib Pajak terhadap Undang-undang dan Peraturan Perpajakan

Pemahaman wajib pajak terhadap undang-undang dan peraturan PBB berfungsi sangat penting karena merupakan elemen dari sikap wajib pajak terhadap undang-undang dan peraturan PBB dan sikap wajib pajak mempengaruhi perilaku perpajakan wajib pajak dan akhirnya perilaku perpajakan mempengaruhi keberhasilan perpajakan. Demi tercapainya target dalam penerimaan pajak bumi dan bangunan maka perlu pula dilihat seberapa besar tingkat pemahaman masyarakat terhadap pajak tersebut. Menurut Siti Kurnia (2010:141), pemahaman perpajakan mempengaruhi sikap terhadap sistem perpajakan yang adil. Apabila seorang wajib pajak semakin paham terhadap undang-undang perpajakan serta ketetapan, ketentuan dan peraturan yang berlaku maka hal tersebut akan menimbulkan rasa sadar atas pentingnya dalam membayar pajak.

3. Faktor PersepsiWajib Pajak tentang Pelaksanaan Sanksi Denda PBB

Persepsi Wajib Pajak tentang Pelaksanaan Sanksi denda PBB Menurut Untung (2004:40) dalam Shidiq (2011:32) persepsi adalah kesan yang diperoleh dari hasil penangkapan panca indera seseorang terhadap suatu figur, kondisi, atau masalah tertentu. Masyarakat akan memiliki sikap sadar terhadap fungsi pajak dan akhirnya 
mematuhi pembayaran PBB, jika persepsi mereka terhadap sanksi, khususnya sanksi denda PBB dilaksanakan secara tegas, konsisten dan mampu menjangkau para pelanggar (Suhardito Sudibyo, 1966:6 dalam Shidiq, 2011:32).

Sanksi pajak merupakan jaminan bahwa ketentuan peraturan perundangundangan perpajakan (norma perpajakan) akan dituruti/ ditaati/ dipatuhi, dengan kata lain sanksi perpajakan merupakan alat pencegah agar wajib pajak tidak melanggar norma perpajakan (Mardia SMO, 2006 dalam Arum, 2012:33)

Pahala (2009:342) menurut Undang-undang Nomor 12 Tahun 1985 secara tegas menetapkan bahwa PBB terutang yang pada saat jatuh tempo pembayaran tidak dibayar atau kurang dibayar dikenakan denda administrasi sebesar $2 \%$ sebulan, yang dihitung dari saat jatuh tempo sampai dengan hari pembayaran untuk jangka waktu paling lama 24 bulan, dimana bagian dari bulan dihitung penuh satu bulan

4. Kualitas Pelayanan Terhadap Wajib Pajak

Pelayanan perpajakan dibentuk oleh dimensi kualitas sumber daya manusia (SDM), ketentuan perpajakan dan sistem informasi perpajakan. Standar kualitas pelayanan prima kepada masyarakat wajib pajak akan terpenuhi bilamana SDM melakukan tugasnya secara profesional, disiplin, dan transparan. Dalam kondisi wajib pajak merasa puas atas pelayanan yang diberikan kepadanya, maka mereka akan cenderung akan melaksanakan kewajiban membayar pajak sesuai dengan ketentuan yang berlaku. Apabila ketentuan perpajakan dibuat sederhana, mudah dipahami oleh wajib pajak, maka pelayanan perpajakan atas hak dan kewajiban mereka dapat dilaksanakan secara efektif dan efisien. Dengan demikian sistem informasi perpajakan dan kualitas SDM yang handal akan menghasilkan pelayanan perpajakan yang semakin baik (Yulianawati, 2011:131)

\section{METODOLOGI PENELITIAN}

Jenis dan Pendekatan Penelitian

Penelitian ini termasuk jenis penelitian explanatory, peneliti melakukan survey dan terjun ke tempat penelitian dengan memberikan kuesioner kepada para wajib pajak di Sukoharjo secara langsung. Penelitian ini menggunakan metode kuantitatif, dimana metode ini digunakan untuk menguji hipotesis.

\section{Metode Pengumpulan Data}

\section{Sumber Data}

Sumber data dalam penelitian ini adalah data primer serta data sekunder. Data primer dalam penelitian ini diperoleh dari sumber asli penelitian dengan cara menyebarkan atau membagikan kuesioner secara langsung kepada para wajib pajak di Sukoharjo. Sedangkan data sekunder penelitian ini diperoleh dari dokumentasi yang dapat dilihat pada DPKAD Kabupaten Sukoharjo, Jurnal dan buku referensi yang berkaitan dengan penelitian, maupun informasi-informasi lain yang berkaitan dengan penelitian ini.

2. Populasi dan Sampel

Menurut Arikunto

(2002:108)

populasi atau universe adalah keseluruhan dari subjek penelitian yang akan diteliti. Dari pengertian tersebut, maka populasi dalam penelitian ini adalah seluruh Wajib Pajak di Kabupaten Sukoharjo. Sedangkan sampel penelitian ini adalah sebagian Wajib Pajak di Kabupaten Sukoharjo. Sampel diambil sebanyak 100 orang responden dengan teknik pengambilan sampel menggunakan teknik random sampling, sehingga setiap Wajib Pajak di Kabupaten Sukoharjo memiliki kesempatan dan peluang yang sama untuk menjadi sampel dalam penelitian ini.

3. Metode Pengumpulan Data

Metode pengumpulan data yang digunakan dalam penelitian ini adalah metode observasi, metode dokumentasi, dan metode kuesioner.

\section{Variabel Penelitian}

Variabel penelitian dalam penelitian ini terdiri dari variabel independen dan variabel 
dependen. Menurut pandangan Sugiyono (2005:

3) variabel independen adalah variabel yang mempengaruhi variabel lainnya. Variabel independen penelitian ini adalah Kesadaran, Tingkat Pemahaman, Pelaksanaan Sanksi dan Kualitas pelayanan. Sedangkan variabel dependen disini adalah kebalikan dari variabel independen, sehingga sifat variabel ini adalah dijelaskan oleh variabel lain. Dari keterangan tersebut, maka variabel dependen penelitian ini adalah Kepatuhan wajib pajak.

\section{Teknik Analisa Data}

1. Analisis regresi berganda

Analisis regresi berganda, analisis ini untuk mengetahui besarnya pengaruh variabel independen atau bebas terhadap Vaiabel Dependen atau terikat. Persamaan regresi berganda dalam penelitian ini adalah: $\mathrm{Y}=\mathrm{a}+$ $\mathrm{b}_{1} \mathrm{X}_{1}+\mathrm{b}_{2} \mathrm{X}_{2}+\mathrm{b}_{3} \mathrm{X}_{3}+\mathrm{b}_{4} \mathrm{X}_{4}+\mathrm{e}_{1}$

Dimana :

$$
\begin{array}{ll}
\mathrm{Y} & =\text { Kepatuhan } \\
\mathrm{X}_{1} & =\text { Kesadaran } \\
\mathrm{X}_{2} & =\text { Pemahaman, } \\
\mathrm{X}_{3} & =\text { Sanksi, } \\
\mathrm{X}_{4} & =\text { Pelayanan } \\
\mathrm{a} & =\text { konstanta }, \\
\mathrm{b}_{1}, \mathrm{~b}_{2}, \mathrm{~b} 3 & =\text { koefisien regresi, dan } \\
\mathrm{e}_{\mathrm{i}} & =\text { faktor pengganggu (error). }
\end{array}
$$

2. Uji signifikansi statistik
a. Uji t
b. Uji F
c. Koefisien determinasi $\left(\mathrm{R}^{2}\right)$
d. Uji Asumsi klasik

\section{HASIL PENELITIAN DAN PEMBAHASAN} Hasil Analisis Deskriptif

a. Deskriptif Variabel Penelitian

Tabel 1 Deskriptif Hasil Penelitian

\begin{tabular}{lcccc}
\hline \multicolumn{1}{c}{ Variabel } & $\mathrm{N}$ & Minimum & $\begin{array}{c}\text { Maks } \\
\mathrm{m}\end{array}$ & $\begin{array}{l}\text { Standar } \\
\text { Deviasi }\end{array}$ \\
\hline Kesadaran Wajib & 100 & 1.83 & 4.83 & 0.572 \\
Sanksi Perpajakan & 100 & 1.00 & 5.00 & 0.941 \\
Tingkat Pemahaman & 100 & 1.71 & 4.86 & 0.683 \\
Kualitas Pelayanan & 100 & 2.57 & 4.56 & 0.355 \\
Kepatuhan Wajib & 100 & 2.57 & 4.71 & 0.418 \\
Pajak & & & & \\
\hline
\end{tabular}

Berdasarkan Tabel 1 dapat diketahui tanggapan dari 100 wajib pajak memiliki penilaian yang tinggi terhadap kesadaran wajib pajak, yang ditunjukkan dengan nilai rata-rata sebesar 3,70 yang berada pada interval $3,41-4,20$, yang berarti kesadaran wajib pajak berada dalam kriteria yang tinggi. Hal ini disebabkan karena masyarakat menyadari bahwa membayar pajak adalah kewajiban sebagai warga negara, dengan membayar pajak bumi dan bangunan berarti ikut membangun daerah, penerimaan dari sektor pajak bumi dan bangunan merupakan pendapatan daerah yang sangat potensial, penerimaan pajak bumi dan bangunan merupakan salah satu penerimaan yang penting bagi pembangunan daerah, dan pajak bumi dan bangunan sifatnya memakasa dan ditetapkan oleh undang-undang.

Dari Tabel 1 dapat diketahui tanggapan dari 100 wajib pajak di Kabupaten Sukoharjo memiliki penilaian yang tinggi terhadap sanksi perpajakan, yang ditunjukkan dengan nilai rata- rata sebesar 3,56 yang berada pada interval 3,41 - 4,20, yang berarti sanksi perpajakan berada dalam kriteria yang tinggi. Hal ini disebabkan karena sanksi yang diberikan atas pelanggaran membayar pajak sesuai dengan besar kecilnya pelanggaran yang sudah dilakukan, sanksi tidak kenal kompromi, dan tidak membeda - bedakan wajib pajak, serta dapat memberikan efek jera.

Berdasarkan Tabel 1 dapat diketahui tanggapan dari 100 wajib pajak di Kabupaten Sukoharjo memiliki penilaian yang tinggi terhadap tingkat pemahaman perpajakan, yang ditunjukkan dengan nilai rata-rata sebesar 3,57 yang berada pada interval $3,41-4,20$, yang berarti pengetahuan perpajakan berada dalam kriteria yang tinggi. Hal ini berarti wajib pajak merasakan wajib pajak memahami tentang pajak, karena mudah diperoleh dari media massa (seperti televisi, dan radio), spanduk, reklame, dan media cetak lainnya, mengetahui fungsi dan manfaat pajak yang digunakan untuk membiayai pembangunan negara dan sarana umum bagi masyarakat, mengetahui bagaimana cara mengisi SPT dengan benar, membuat laporan keuangan, dan cara membayar pajak dengan benar, serta memahami bahwa dalam Undang-undang perpajakan, bagi Wajib Pajak yang terlambat 
atau tidak membayar pajak dapat diberikan sanksi administrasi (denda) dan sanksi pidana (penjara).

Dari Tabel 1 dapat diketahui tanggapan dari 100 wajib pajak di Kabupaten Sukoharjo memiliki penilaian yang tinggi terhadap kualitas pelayanan, yang ditunjukkan dengan nilai rata-rata sebesar 3,83 yang berada pada interval $3,41-4,20$, yang berarti kualitas pelayanan berada dalam kriteria yang tinggi. Hal ini disebabkan karena petugas pajak memberikan penyuluhan perpajakan kepada wajib pajak, memberikan kemudahan kepada wajib pajak bumi dan bangunan dalam membayar pajaknya, petugas pajak memberikan pelayanan dengan baik, cepat, dan tepat, serta selalu berpenampilan rapi dalam melayani wajib pajak sehingga memberikan kenyamanan kepada wajib pajak.

Dari Tabel 1 dapat diketahui tanggapan dari 100 wajib pajak di Kabupaten Sukoharjo memiliki penilaian yang tinggi terhadap kepatuhan wajib pajak bumi dan bangunan, yang ditunjukkan dengan nilai rata-rata sebesar 3,83 yang berada pada interval 3,41 - 4,20, yang berarti kepatuhan wajib pajak bumi dan bangunan berada dalam kriteria yang tinggi. Hal ini disebabkan karena wajib pajak paham atau berusaha untuk memahami semua peraturan pajak yang berlaku, Saya selalu mengisi surat pemberitahuan objek pajak dengan lengkap dan benar, selalu membayar pajak bumi dan bangunan tepat waktu, pernah tidak membayar pajak bumi dan bangunan tepat waktu pernah tidak membayar pajak bumi dan bangunan tepat waktu, tidak pernah memiliki tunggakan pajak, dan menyerahkan surat pemberitahuan objek pajak yang sudah terisi ke Dinas Pendapatan Daerah.

\section{b. Model Persamaan}

Untuk melihat hasil analisis pengaruh dari keempat variabel independen (X) terhadap variabel dependen (Y) terdapat pada tabel dibawah ini :
Tabel 2 Hasil AnalisisRegresi Linier Berganda

\begin{tabular}{lccr}
\hline Variabel & Koefisien & thitung & Probabilitas \\
\hline Konstanta & 0.498 & & .210 \\
Kesadaran & 0.206 & 1.261 & 0.000 \\
Sanksi & 0.165 & 3.984 & 0.000 \\
Tingkat & 0.219 & 5.281 & 0.000 \\
Kualitas & 0.315 & 4.968 & 0.000 \\
F hitung & & 26.471 & \\
$\mathrm{R}^{2}$ & & 0.502 & \\
\hline
\end{tabular}

Pada penelitian ini digunakan model persamaan regresi linear berganda sebagai berikut :

$$
\begin{aligned}
& Y=a+b 1 X 1+b 2 X_{2}+b 3 X_{3}+b 4 X 4 \\
& Y=0,498+0,206 X_{1}+0,165 X_{2}+0,219 \\
& X 3+0,315 X 4
\end{aligned}
$$

c. Koefisien Determinan $\left(\mathrm{R}^{2}\right)$ dan Uji F

Koefisien determinasi berganda menunjukkan besarnya persentase pengaruh semua variabel bebas terhadap nilai variabel terikat.Besarnya koefisien determinasi dari nol sampai satu. Semakin mendekati nol besar koefisien determinasi, maka semakin kecil pengaruh semua variabel bebas terhadap variabel terikat. Sebaliknya semakin mendekati 1, semakin besar pula pengaruh semua variabel bebas terhadap variabel terikat. Dari Tabel 2 juga dapat diketahui koefisien determinasi $\left(\mathrm{R}^{2}\right)$ sebesar 0,502. Dengan nilai koefisien determinasi sebesar 0,502, maka dapat diartikan bahwa 50,2\% Kepatuhan wajib pajak bumi dan bangunan dapat dijelaskan oleh keempat variabel bebas yang terdiri dari kesadaran wajib pajak, sanksi perpajakan, pengetahuan perpajakan, dan kualitas pelayanan. Sedangkan sisanya sebesar $49,8 \%$ dipengaruhi oleh variabel lain yang tidak dimasukkan dalam model penelitian.

\section{d. Uji t}

Berdasarkan Tabel 2 dapat diketahui nilai thitung dan nilai probabilitasnya untuk masing-masing variabel bebasnya telah 
diketahui dan dapat dijadikan sebagai dasar pengambilan keputusan dengan cara membandingkannya dengan tingkat signifikansi 0,05.

1). Pengujian $\mathrm{t}$ hitung pada Variabel Kesadaran Wajib Pajak (X1)

$$
\text { Hasil pengujian signifikansi }
$$
menunjukkan bahwa variabel kesadaran wajib pajak (X1) terdapat nilai thitung sebesar 3,984 dan tabel sebesar 1,6595 yang berarti $3,984>1,6595$. Nilai tersebut dapat membuktikan Ho ditolak yang berarti bahwa ada pengaruh variabel kesadaran wajib pajak secara signifikan terhadap kepatuhan wajib pajak bumi dan bangunan, dengan demikian hipotesis pertama terbukti.

Hasil penelitian ini sesuai dengan penelitian oleh Banyu Utomo (2011) menunjukkan bahwa secara parsial kesadaran wajib pajak berpengaruh secara signifikan terhadap kepatuhan wajib pajak.

2). Pengujian $t$ hitung pada Variabel Sanksi Perpajakan (X2)

Hasil pengujian signifikansi menunjukkan bahwa variabel sanksi perpajakan $\left(X_{2}\right)$ terdapat nilai thitung sebesar 5,281 dan tabel sebesar 1,6595 yang berarti 5,281> 1,6595. Nilai tersebut dapat membuktikan Ho ditolak yang berarti bahwa ada pengaruh variabel sanksi perpajakan secara signifikan terhadap Kepatuhan wajib pajak bumi dan bangunan, dengan demikian hipotesis kedua terbukti.

Hasil penelitian ini sesuai dengan penelitian Laura Yohana, (2016) tentang menunjukkan bahwa secara parsial sanksi perpajakan berpengaruh signifikan terhadap kepatuhan wajib pajak.

3). Pengujian thitung pada Variabel Tingkat Pemahaman Perpajakan (X3)

$$
\text { Hasil pengujian signifikansi }
$$

menunjukkan bahwa variabel tingkat pemahaman perpajakan (X3) terdapat nilai thitung sebesar 4,968 dan tabel sebesar
1,6595 yang berarti 4,968> 1,6595. Nilai tersebut dapat membuktikan Ho ditolak yang berarti bahwa ada pengaruh variabel tingkat pemahaman perpajakan, dengan demikian hipotesis ketiga terbukti.

Hasil penelitian ini sesuai dengan penelitian yang dilakukan oleh Banyu Utomo, (2011) menunjukkan secara parsial pengetahuan/pemahaman perpajakan berpengaruh secara signifikan terhadap kepatuhan wajib pajak.

d. Pengujian $t$ hitung pada Variabel Kualitas Pelayanan (X4)

Hasil pengujian signifikansi menunjukkan bahwa variabel kualitas pelayanan (X4) terdapat nilai thitung sebesar 3,875 dan tabel sebesar 1,6595 yang berarti $3,875>1,6595$. Nilai tersebut dapat membuktikan Ho ditolak yang berarti bahwa ada pengaruh variabel kualita pelayanan secara signifikan terhadap Kepatuhan wajib pajak bumi dan bangunan, dengan demikian hipotesis keempat terbukti.

Hasil penelitian ini sesuai dengan penelitian yang dilakukan oleh Imam dan Dewi, (2015) menunjukkan kualitas pelayanan secara simultan berpengaruh positif terhadap kepatuhan wajib pajak bumi dan bangunan di Kabupaten Sukoharjo.

\section{KESIMPULAN}

Berdasarkan hasil penelitian seperti yang telah diuraikan pada bab sebelumnya dapat ditarik beberapa kesimpulan yaitu :

1. Kesadaran wajib pajak tentang perpajakan berpengaruh signifikan terhadap kepatuhan wajib pajak bumi dan bangunan. Hal ini berarti sikap sukarela masyarakat untuk mendaftarkan diri menjadi wajib pajak, sikap tertib peraturan,pemahaman tentang pajak,tidak menunggak pembayaran, dan kepercayaan penuh terhadap aparat pajak mempengaruhi kepatuhan wajib pajak. Tidak harus menjadi ahli perpajakan masyarakat hanya harus mengetahui dahulu hal mendasar tentang pajak, mengetahui cara membayar pajak, cara menghitung pajak, sanksi pajak,dll.Ini berarti 
semakin tinggi kesadaran wajib pajak maka tingkat kepatuhannya masyarakat Kabupaten Sukoharjo juga semakin tinggi.

2. Sanksi perpajakan berpengaruh signifikan terhadap kepatuhan wajib pajak bumi dan bangunan. Penerapan sanksi perpajakan merupakan jaminan bahwa ketentuan perundang-undangan perpajakan akan dituruti, ditaati, dan patuhi wajib pajak atau dengan kata lain sanksi perpajakan merupakan alat agar wajib pajak tidak melanggar norma perpajakan. Hal ini berarti semakin tinggi sanksi pajak maka tingkat kepatuhannya semakin meningkat.

3. Pemahaman perpajakan berpengaruh signifikan terhadap kepatuhan wajib pajak bumi dan bangunan. Pemahaman perpajakan adalah kemampuan atau seorang wajib pajak dalam memahami peraturan perpajakan baik itu soal tarif pajak berdasarkan undangundang yang akan mereka bayar maupun manfaat pajak yang akan berguna bagi kehidupan mereka. Hal ini berarti semakin tinggi pengetahuan perpajakan maka tingkat kepatuhannya juga semakin meningkat.

4. Kualitas pelayanan berpengaruh signifikan terhadap kepatuhan wajib pajak bumi dan bangunan. Pelayanan yang diberikan aparat pajak terhadap wajib pajak PBB diantaranya dalam menentukan PBB, penetapan SPPT telah adil sesuai dengan yang seharusnya, aparat pajak memperhatikan terhadap keberatan terhadap pengenaan pajaknya, memberikan penyuluhan kepada wajib pajak di bidang perpajakan khususnya PBB dan kemudahan dalam pembayaran PBB. Hal ini berarti semakin baik pelayanan maka tingkat kepatuhannya juga semakin meningkat.

\section{REFERENSI}

Biro Pusat Statistik. 20013. Kabupaten Sukoharjo Dalam Angka. Kabupaten Sukoharjo: BPS.

Ghozali, Imam.2005. Analisis Multivariat dengan Program SPSS. Semarang: Badan Penerbit Universitas Diponegoro.
Ilyas, WirawanB dan Rhicard Burton. 2004. Hukum Pajak. Jakarta: SalembaEmpat.

Juniriadi. 2008. Analisis Realisasi Penerimaan Pajak Bumi dan Bangunan Di Kabupaten Lampung Utara Tahun 20032007. Tesis Program Pasca Sarjana MM FE-Universitas Bandar Lampung: http://www.find-pdf.com/cari-pajak.html.

Mayulia, Tri.2009. Evaluasi Terhadap Potensi Pendapatan Daerah Dari Sektor Pajak Bumi Dan Bangunan(Studi Kasusdi Pemda Kabupaten Klaten). Skripsi FE-UMS: http://www.find- $\quad$ pdf.com/caripajak.html.

Payamta, Aryani dan Rahmawati. 1994. Analisis Faktor-faktor Yang Mempengaruhi Kepatuhan Wajib Pajak Dalam Memenuhi Kewajiban PBB. Penelitian Berkelompok Dana BRK Tahun 1994/1995.FE-UNS.

Peraturan Daerah Nomor 5 Tahun 2000 Tentang Badan Perwakilan Desa.

Riyadi,Bagus. 2007.Pengaruh Faktor Tax Payer Terhadap Keberhasilan Penerimaan Pajak Hotel(Studi Empiris Terhadap Wajib Pajak Pungut Hotel di Surakarta). Skripsi FEUNS : Tidak dipublikasikan.

Santoso, Singgih. 2002. Buku Latihan Statistik Parametrik. Jakarta: PT Elex Media Komputindo.

Soemitro, Rochmat dan Sofyan Effendi. 2010. Pajak Bumi dan Bangunan. Bandung: PT Refika Aditama.

Suhardito,Bambang. 2006. Pengaruh Faktorfaktor Yang Melekat Pada Diri Wajib Pajak Terhadap Keberhasilan Penerimaan PBB. Tesis FE-UGM. Tidak dipublikasikan. 
Suhardito,Bambang danBambang Sudibyo.2010. Pengaruh Faktor-faktor Yang Melekat Pada Diri Wajib Pajak Terhadap Keberhasilan Penerimaan PBB. SNA II: Ikatan Akuntan Indonesia.

Sularso, Sri. 2004. Buku Pelengkap Metode Penelitian Akuntansi : Sebuah Pendekatan Replikasi. Yogyakarta: BPFE.

Suranto.2010. Analisis Faktor-faktor Yang Mempengaruhi Kepatuhan Wajib Pajak Dalam Membayar PBB Sektor Pedesaan di Kecamatan Nogosari Kabupaten Boyolali. Skripsi FE-UNS: Tidak dipublikasikan.

Undang-undang Nomor 12 Tahun 1994 tentang Pajak Bumi dan Bangunan.

Undang-undang Nomor 032 Tahun 2004 Tentang Pemerintahan Daerah.

Peraturan Daerah Kabupaten Sukoharjo Nomor 13 Tahun 2011 tentang Pajak Bumi dan Bangunan Perdesaan dan Perkotaan

Peraturan Bupati Sukoharjo Nomor 15 Tahun 2012 tentang Pedoman Pelaksanaan Peraturan Daerah Nomor 13 Tahun 2013 tentang Pajak Bumi dan Bangunan Perdesaan dan Perkotaan

Waluyo. 2002. Perpajakan Indonesia. Salemba Empat: Jakarta. 